\title{
PARTISAN MEDICAL CARE THROUGH THE EYES OF DOCTORS
}

\section{PARTIZANSKO ZDRAVSTVO U OČIMA LIJEČNIKA}

\author{
Pia Žižek*
}

\section{SUMMARY}

The Second World War created a caesura in various spheres of life, including medical care. Many doctors and nurses in Slovenia joined the Partisan movement and helped organise medical care. The first activities were undertaken in 1942, followed a year later by the development of the first rudimentary, clandestine partisan medical stations acting as hospitals. Nearly 15000 patients with injuries and illnesses were treated in such partisan medical facilities. The staff included 244 doctors and dentists, 260 medical students, 38 nurses and more than 3000 ad hoc trained medics. This article presents the "Celje" partisan hospital from the Upper Savinja Valley, focusing on the testimonies of Partisan doctors and other witnesses who provided first-hand accounts about everyday life in this and other Partisan medical facilities. The main source of information was the notes of surgeon Dr Robert Kukovec, which date from the final year of the war. Dr Kukovec was among the few individuals who left behind a written account of the wartime events they had witnessed, offering an insight into the tragedy of war. His account also depicts many sombre moments but also rare bright ones, in particular the yearning for the freedom that destiny prevented Dr Kukovec from experiencing, given that he was killed less than a month before the end of the war.

Keywords: Second World War, Slovenia, Styria, history of medicine, Partisan medical care, Partisan hospital, Partisan doctors

Student of Laboratory Biomedicine, Faculty of Pharmacy, University of Ljubljana, Ljubljana, Slovenia. ORCID: https://orcid.org/0000-0003-0187-4191.

Correspondence Address: Pia Žižek, Ulica Ključarja Kožuha 2, SI-3000 Celje, Slovenia. E-mail: pia. zizek99@gmail.com. 


\section{INTRODUCTION}

In the interwar period, Slovenian territory saw a rise in the number of new health centres, hygiene and social care establishments, following the state policy according to which the population was to be provided with the best possible health care (Zupanič Slavec, 2005, p. 55). In addition to public hospitals, health services were also provided by privately-owned institutions. The combat against infectious diseases was the domain of social care and hygiene establishments, with national health centres, dispensaries and anti-tuberculosis dispensaries located in major cities, and health stations in small towns. Health services in rural areas were provided by the banate ${ }^{\mathrm{r}}$ doctor (Krajevni leksikon, 1937, p. I8).

Just before the outbreak of war, in 1939, the Drava banate, comprising territory that was slightly under the size of today's Slovenia and with a population of I 144 298, had I6 hospitals: two public, eight banate and six others, with a total of 3248 beds. The staff included I 43 doctors and 489 other health care professionals. In the $1938 / 39$ academic year, the Medical Faculty in Ljubljana had i62 students (SIstory, 20II-202I, p. 352-353, 380-38I). The faculty had existed since 1919; however, it was incomplete, with initially two and subsequently three classes after 1940/4I; it was mandatory for the students to go abroad to complete their studies (Fettich, 1993, p. 35-36).

The medical students included Dr Robert Kukovec, who will be presented in more detail below. Dr Kukovec was born in Igro in Innsbruck to an educated Slovenian-Russian family. His father Janko was from Ljutomer, while his mother Klara had a wealthy Russian Jewish ancestry. His mother was among the first female medical doctors in Slovenia, and his father was a construction engineer; they both had studied abroad (Horvat, 20II, p. 3I-53). Robert attended high school in Maribor and later studied medicine in Vienna and Innsbruck, where he graduated as a "doctor of general medicine" in 1934. He completed his residency in the hospitals in Maribor and Ljubljana, followed by a voluntary assistantship at the Institute of Pathology and Anatomy in Zagreb with Professor Dr Sergey Nikolayevich Saltykov (Wikipedija, 2018) between May 1935 and October 1936. He spent the next two years assisting Professor Julije Budisavljević (Wikipedija, 202I) at the surgical clinic in Zagreb. He was then awarded a stipend by the French government and worked for nearly two years as an international assistant in several hospitals in France: at Hôpital

1 Banates (banovina) were administrative subdivisions of the Kingdom of Yugoslavia that were introduced in 1929. 
Laennec (clinic for pulmonary surgery), in Strasbourg with Professor Leriche (Nature, 1938) and in Paris with Professor Maurice Chevassu (Wikipedia, 20I9) at a urology clinic. In I940, he continued as an assistant at the surgical clinic in Zagreb, where he remained until February I94I.

The situation drastically changed during the Second World War with the Nazi occupation. The region of Styria came under the control of the Germans, who reorganized the health service in compliance with their rules (Počivavšek, 20I8, p. I58).

\section{Partisan medical CARE}

During the Second World War, many doctors and other medical staff joined the partisans. The origins of partisan medical care go back to I94I when the partisans started collecting medical supplies and organized first aid courses, practical courses in small surgery for medical students and courses for nurses and scrub nurses. Organized medical care in the field emerged a year later, followed by the first clandestine, rudimentary partisan medical stations in I943. During the war, nearly 15000 patients with injuries and illnesses were treated this way (Valenti, I994, pp. 262-263). A total of 244 doctors and dentists, 260 medical students, 38 nurses and more than 3 ooo ad hoc trained medics were involved in the provision of medical care to Slovenian Partisans. Assistance was also administered in the field, which relieved the partisan units, increasing their operational ability and boosting their morale (Fajdiga, I998, p. 35). Medical care included medical institutions and staff, care for patients, the provision of medicinal products and medical supplies, evacuation of patients, and medical staff training (Valenti, I994, p. 262). Given its scope under the circumstances, it is safe to say that Partisan medical care during the war was an organized and coordinated activity.

In Styria, the ill and the injured first received urgent medical care, after which they convalesced on relatively safe farms and in provisional shelters where a small number of ad hoc medics or field agents cared for them. It was only when the number of doctors grew in the spring of 1942 that care in the field began to be administered in a more organized way. To this purpose, the partisans began to develop a network of secret medical stations, which often functioned in very dire conditions (Valenti, I994, p. 262-263). In the region of Celje, several small partisan medical stations were established under the guidance of medics or doctors. Especially important were the facilities that emerged in early I944 along the path of the $14^{\text {th }}$ Division (Planinšek, I977, p. 
516), one of the largest Partisan units, when it deployed from Bela Krajina in SE Slovenia to assist the partisans in Styria, following the route SedlarjevoBohor-Štore-Konjiška gora-Paški Kozjak-Pohorje-Graška gora-Mozirske planine (Kregar, 2009, p. I00-IOI). Dr Herbert Zaveršnik, the head of Partisan medical facilities and care in Styria, also responsible for the collection and distribution of medical supplies dropped by the English and American planes south and west of the Pohorje mountain range, wrote the following:

"Before every airdrop, we were given the exact coordinates of the designated drop zone. [...] The crew waved at me and then started pushing elongated cigar-like cylinders, which we called 'containers', through the openings in the fuselage. Each bundle hung under a canopy. I watched eagerly as the parachutes opened, swaying slowly along with the load they carried as they descended into the valley, where several partisans and officials collected them and made sure they were distributed accordingly." (Zaveršnik, I996, p. 139-I40)

The Allies airdropped supplies into the liberated parts of Pohorje in Upper Savinjska Valley and in Kozjansko between August and October 1944 (Kregar, 2009, p. 107-II2).

Today, it is difficult to imagine the conditions under which partisan medical care was provided, as the examples below will illustrate.

In Kozjansko, a part of southern Styria, medical service was virtually nonexistent in the first few years of the war. Prior to the arrival of the $14^{\text {th }}$ Division, it was mostly reduced to hiding patients in bunkers; hence, their recovery was slow. The first bunkers were vividly described by Dr Ivan Kopač-Pavček:

"I shall never forget our first medical stations in the most difficult moments of our struggle for Styria. These first "hospitals" were dark corners in the attics of solitary, poor farmhouses, carefully hidden away behind all sorts of clutter and planks of wood, where three or four partisans with severe injuries were holding their breath. Oftentimes, the hospitals were also dark holes in piles of straw on the floor or in the stable, next to the manger, shaped as a bunker made of planks of wood, covered with straw and manure. Some of these stations could be found in the pigpens, in beehives or in cellars. These hideaways, often harbouring several wounded partisans, were so carefully disguised that not even a watchful eye could notice anything suspicious. These first "hospitals" were built by the local population, who also carefully hid away the patients, making sure to save them from the enemy." (Mrvič, 1974, p. 188) 
Here is how the commander of the Medical Care Training Unit at the $14^{\text {th }}$ Division Headquarters described the situation at a field hospital in Kozjansko (in the vicinity of Planina) in late I944:

"The hospital barracks were furnished with double bunk beds. The medicine cabinet where other accessories were also stored stood next to the entrance. For the patients with severe injuries, three separate beds were placed opposite the bunk beds. Other barracks for the personnel were located in the immediate vicinity. Later, a small log cabin was added next to the hospital barracks, serving as the operating room. Further down from the hospital, we built two well-camouflaged bunkers to be used in case of emergency. The facility was code-named R 9; it was well stocked with food and medical supplies, my problem being that I was used to Italian medicinal products instead of the English ones. However, clothes and shoes for the team were in extremely short supply. Later, the personnel put on some overalls made of Allied parachutes, but the footwear problem remained. [...] Life in the hospital, which was always full, followed the usual routine. Even though we had patients with severe injuries, I can safely say that the mortality rate was extremely low." (Defar, 1972)

Medical care in the Upper Savinja Valley, part of the $4^{\text {th }}$ Operative Zone, the supreme Partisan military command for northern Slovenia, was organised by Dr Peter Držaj. A strong inflow of patients on the liberated territory required the construction of medical care facilities, and training courses were held to train the much-needed medics. The attendees of these courses learned how to

"administer first aid and artificial respiration to the wounded, stop the bleeding using the Esmarch method, use the appropriate technique to carry the wounded, provide improvised immobilisation of broken extremities, dress wounds on all parts of the body, use various disinfection and sterilisation techniques, etc." (Cestnik, I95I, p. I04)

The rise and development of medical care in Styria, however, was delayed by the winter military offensive in December 1944, which destroyed nearly all medical facilities, except for those on Pohorje and Kozjansko. Ivan Cestnik, a doctor in the $4^{\text {th }}$ Operative Zone, wrote the following:

"The doctors were always very busy. There was as much going on as if we were at a surgical clinic. In addition to ambulatory care and scheduled examinations, there was a steady inflow of injured patients. [...] We had to determine the type of injury and the urgency of the required surgical treatment. We tended to every single wound, with no exceptions: we removed blood-soaked 
dressings, fixed new splints, and followed up on the surgical treatment provided in the field. Sometimes, we also had to amputate, perform abdominal surgery, remove projectiles etc. [...] Among other things, Dr Kukovec performed appendectomies, treated bladder injuries and vascular aneurysms. Because we were short of ether, English chloroform was used to anaesthetise patients. We often had to improvise from scratch. Quality surgical instruments were in particularly short supply. The nurses sewed scrubs from the silk of the English parachutes. We also had to overcome the problem of sterilisation. Using sheet metal, the repair shop manufactured a pressurised steam steriliser that was based on Kukovec's idea. The carpenters built wooden operating tables, Dietrich splints, Braun splints, and abduction splints, which we also provided to other hospitals and brigades." (Cestnik, 1951, p. I02; Cf. also: Rogers, 2018, p. I46, 205, 224)

To sum up, a circular written by Dr Robert Kukovec titled Overview of the stages of partisan field medical care treatment dated II November 1944, states:

"One of the main differences between treating the wounded in peacetime and in war is that in peacetime a patient is provided with all necessary care in one place, while a wounded person is treated at different locations during the war. On the front lines, medical care is more primitive; the further away from the front lines, the more professional and sophisticated it gets." (Cestnik, 195I, p. 103)

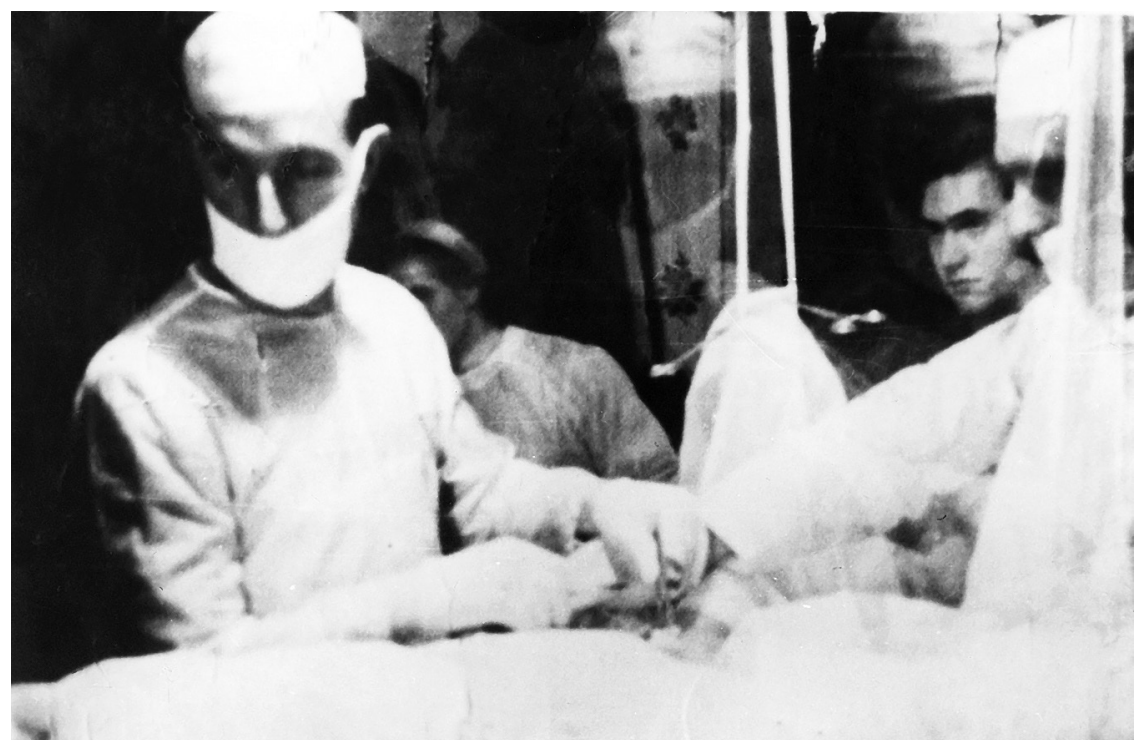

Figure r. Dr Robert Kukovec during surgery.

Museum of Recent History Celje. 


\section{Partisan medical care in the Upper Savinja Valley}

In 1943, the Partisans divided Slovenia into Operative Zones, Styria becoming the $4^{\text {th }}$ Operative Zone. The command of the zone was also tasked with the organisation of partisan medical care, which intensified with the arrival of a large Partisan unit - the $14^{\text {th }}$ Division. The process involved the construction of secret medical stations in safe, remote locations to tend the patients with severe injuries, and a medical unit was established at the $4^{\text {th }}$ Operative Zone headquarters. Few people knew where the stations were located; usually, only the hospital personnel had this information. The buildings were constructed in a rudimentary manner. They could be made as underground bunkers (root cellars), half-hidden constructions made of roughly hewn beams. Those barracks made of wooden planks with windows and doors were above-standard. Often, hospital facilities were built under large overhanging rocks. They were mainly covered with tree bark, shingles or, rarely, planks of wood. In simple, provisionary constructions, the wounded and the hospital staff lived together in one room. Larger hospitals consisted of several buildings. Each hospital had its management, consisting of the superintendent (usually either a doctor or a trained medic), a commissar and a quartermaster. Hospitals kept mandatory administrative records. Larger hospitals had special barracks that served as operating theatres for more complicated surgery. Surgeons either worked permanently in these hospitals or came from elsewhere if needed. The basic rule was to keep the location secret and observe confidentiality. Each hospital had its own meeting point where the wounded, supplies and information were collected. The wounded were carried or led from the meeting point by the hospital staff, mainly at night or after they had been blindfolded. Most partisan medical facilities had emergency evacuation plans, according to which the patients with severe injuries would be hidden at predetermined safe locations, while the mobile patients and the staff would leave the compromised area. A key element was the supply of medicinal products, medical supplies and food. The organisational and technical aspects of the supply activities were the responsibility of the quartermasters. In the summer of 1944 , the materials were also supplied by the Allied forces. The Allies parachuted the materials into drop zones that were determined in secrecy between the partisans and the local Allied missions (Združenje borcev za vrednote NOB Zgornje Savinjske doline, 202I).

In the Upper Savinja Valley, partisan medical facilities operated relatively smoothly until the great German winter military offensive in December 1944. 


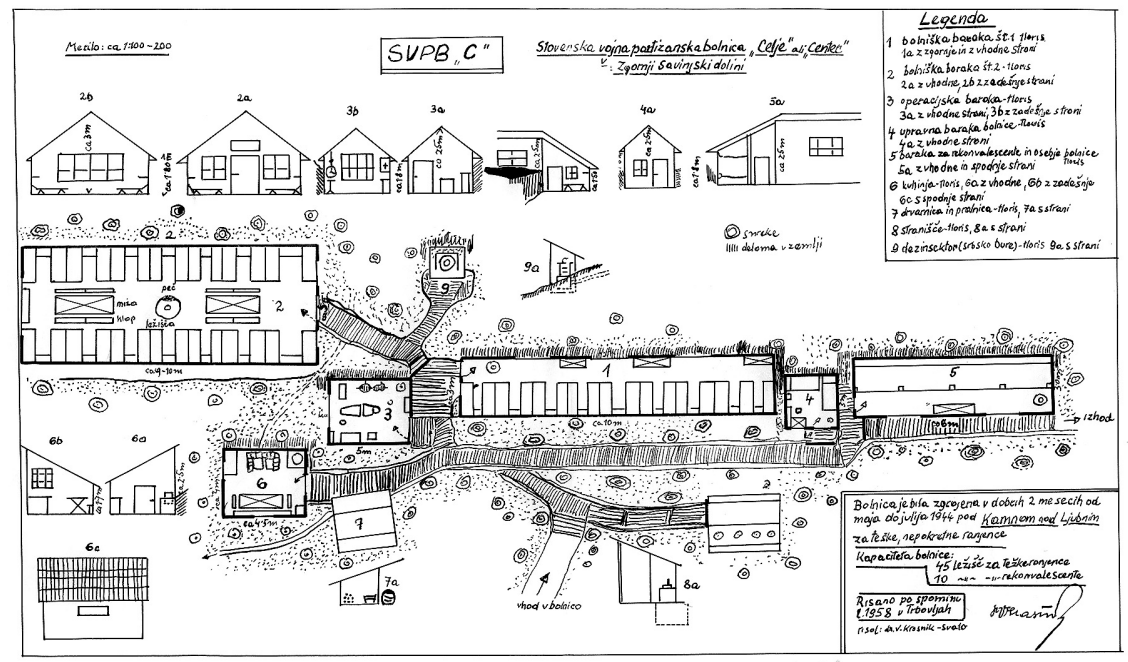

Figure 2. A sketch of the "Celje" Partisan hospital, drawn from memory by Dr Virgil Krasnik in I958. Museum of Recent History Celje.

\section{The "Celje" Partisan hospital}

The "Celje" SVPB (Slovenian Partisan Military Hospital) was built by the partisans in the spring and summer of 1944 in the hills above Ljubno, at I $200 \mathrm{~m}$. Ignac Zupanc, who came to the $4^{\text {th }}$ Operative Zone following recuperation from a wound sustained during the march of the $14^{\text {th }}$ Division, remembers being designated to the team responsible for building a partisan hospital in the Upper Savinja Valley in I944:

"We worked from dawn till dusk. We first dug the foundations for the hospital room, followed by cutting down pine trees and tying logs. [...] Once the barracks was done, we camouflaged it well, so it was impossible to see before you actually reached it. In the same way, we built an operating barracks next (covered from the inside with parachute silk), a kitchen and a barracks for the personnel. The attic was built later and was mainly intended to be used by those with minor injuries." (Zupanc, n.d.)

In May 1944, Dr Virgil Krasnik, a doctor in the Trbovlje hospital before the war, was appointed the superintendent of the "Celje" hospital in the making:

"Except for the unbelievable willpower of my faithful and hardworking companions, some tools, and the wood found in the forest, I basically had nothing to start with. But the self-sacrifice, perseverance, and ingenuity of the entire 
team made it possible to build a hospital barracks and a special barracks for the recovering patients and for the hospital personnel, to build and furnish the operating barracks, to improvise a workstation for exterminating insects, and to build the toilets - in practically no time. Once we were done with this part, we moved on to the woodshed and the laundry room. We also built a small administrative barracks. [...] Soon, our hospital was ready to admit its first patients for the ensuing struggle for the liberated territory." (Krasnik, I955)

The "Celje" SVPB was the general joint name for two partisan hospitals. The first one was used for bedridden patients with severe injuries and comprised the following: two large barracks for the patients, operating barracks, administrative barracks, the barracks for the convalescent patients, a kitchen, a supply unit, and a disinfection room (Šeber, I968). Underground bunkers serving as storage rooms for food, materials, and medical supplies were located nearby. About a fifteen-minute walk away, a secluded spot hid another underground bunker for the evacuation of immobile patients with severe injuries. The second part of the hospital was about an hour away from the first one and was used for the ill or patients with minor injuries. It comprised wooden barracks with bunk beds and a kitchen.

Both parts of the hospital were located on a steep slope in the forest, a three-hour walk from Ljubno. No paths led towards the hospital. In winter, one could access it by crossing a stream. At times of excessive snowfall, the hospital became inaccessible. The wounded were admitted at a meeting point about an hour's walk away, located in a farmhouse. The owner of the farmhouse also owned the land on which the hospital was built. The wounded were transported to the hospital only at night. For safety reasons, they were blindfolded upon arrival and departure.

The unit for the patients with severe injuries comprised approximately I5 staff members (superintendent, doctor, nurses, political commissar and quartermaster), while the unit for the patients with minor injuries had around nine staff members. Auxiliary staff positions (quartermaster, medics and stretcher-bearers) were mostly filled by the convalescent injured partisans. Initially, medical supplies were relatively easy to obtain from various local military pharmacies in the area. However, the situation deteriorated during and after the German military offensive in the winter of 1944/45, when all supply routes (for both medicine and food) were interrupted (Šeber, I968).

The construction of the "Celje" hospital was overseen by Dr Peter Držaj, who was responsible for the establishment of partisan hospitals in the Upper 
Savinja Valley. Here is how Dr Virgil Krasnik remembers the situation in this medical facility:

"Once the hospital was finished, Dr Držaj and I chose its name - we decided to call it SVPB "C" (or "Celje"). The hospital could admit 45 patients with severe injuries and 15 convalescent patients. In the attic, there was space for about 40 immobile patients with minor injuries. The hospital was built exclusively for patients with severe injuries and was supposed to be the main military surgical hospital for the entire Upper Savinja Valley. The operating room had nearly all the accessories needed to perform operations and plastering. [...] Based on my plans, we created all the necessary equipment - operating table, instrument table, anaesthesia table, and various splints. We kept the following records: records of admitted injured fighters, the operating protocol, a description of injuries, records of the patients who had died, and a list of staff. In our hospital, we treated patients with severe injuries. We operated on and plastered, for example, all bones fractured by bullets, and we also treated traumatic aneurysms of femoral arteries, patients with shots to the abdomen or the bladder etc. We also operated on serious hernias. I was the main surgeon. In August and September, I was assisted by Dr Žiga [Červinka]; Dr Dušan [Šeber] joined us a while later, followed by Dr Robert [Kukovec], who was the last doctor in this hospital." (Krasnik, 1955, p. I-2)

Dr Krasnik was an excellent organiser:

"I drew the plans for the essential equipment of the operating barracks and other accessories. The carpenter carefully followed my plans and made everything look very nice. We also prepared the necessary equipment for sterilising wound dressings, scrubs and instruments. [...] We were given snow-white parachute silk, which we used to cover the ceiling and walls of the operating barracks. [...] As for the instruments, I was given a few from the field, just in time, but I mainly used the instruments that I had sent to the Partisans from the Trboulje hospital before my departure. The field agents collected medicinal products, disinfectants and wound dressings and sent them to us. We were also given ether for anaesthesia and some ready-made plaster bandages. [...] Providing equipment for the hospital was the easy part; finding the personnel was much more difficult. [...] Both hospitals and the supply unit only had twenty people. [...] Each and every staff member worked with an enormous degree of self-sacrifice and love. If there was a large influx of injured fighters, we triaged them and tended to them depending on the degree of urgency involved. Professional work took place just like as any other hospital. When there were no severe battles, we also operated on serious hernias and complications 
from shot wounds. Dr Žiga Červinka and I, for example, performed successful surgery on the left femoral artery, while Dr Robert Kukovec and I performed operations on the urinary tract and the head. Our facility had all the necessary accessories to treat fractured bones ${ }^{2}$ - with some improvisation, of course. [...] At the end of October 1944, I was reassigned, and Dr Štefan [Dr Dušan Šeber] became the superintendent of the hospital and Dr Robert Kukovec its surgeon." (Krasnik, 1959, p. 2)

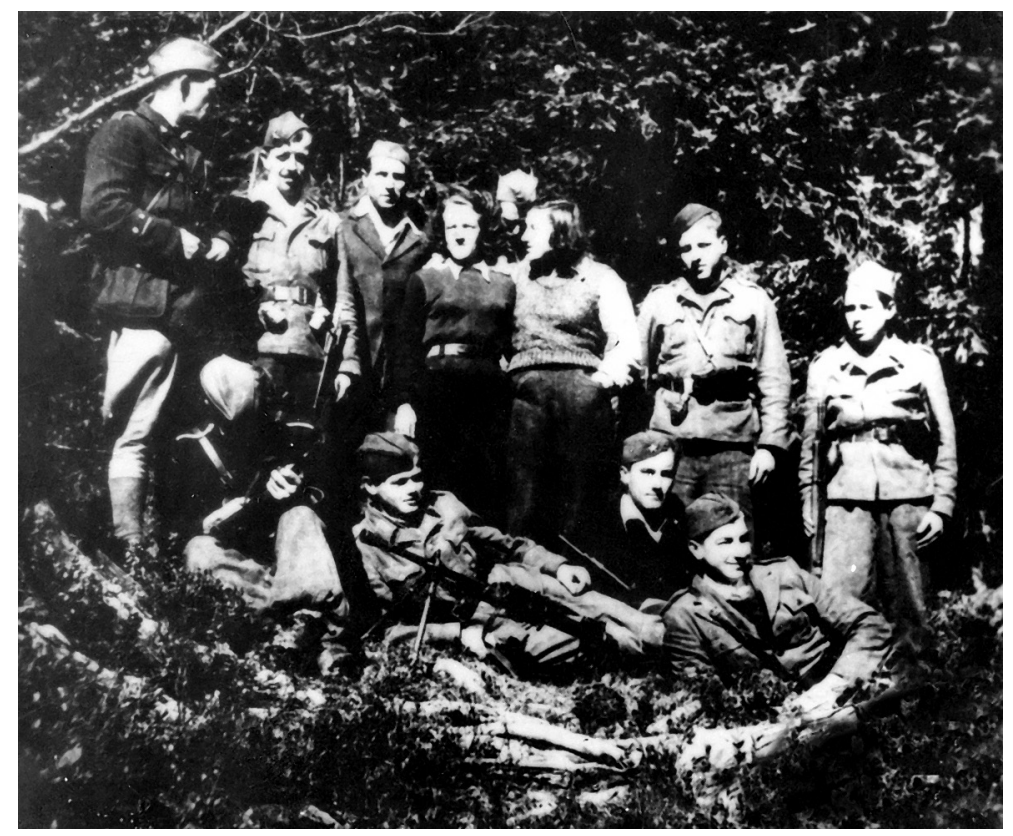

Figure 3. A group photo of the personnel of the "Celje" Partisan hospital; Dr Virgil Krasnik stands on the far left, while the commissar of the hospital, Dr Ignac Zupanc, lies on the right. Museum of Recent History Celje.

This is how Ignac Zupanc remembered everyday life at the hospital ( $\mathrm{Zu}$ panc, n.d., p. I-2):

"Life in the hospital followed the rules defined by my fellow surgeon Žiga [Červinka], who always did his best to keep the injured fighters satisfied. Body temperature was taken every day in the morning and in the evening, and the data were entered in the chart on the patient's bed. Every morning Dr Žiga

2 Dr Kukovec wrote about bone fracture treatment in exceptional circumstances in the final issue of the Partisan Medical Gazette; however, he probably never saw his own article in print, given that it was published in April 1945, the month of his death (Kukovec R., 1945, p. 34-44). 
took the rounds, accompanied by a nurse. This was followed by operations if necessary, which I attended regularly. The patients were updated on the frontline developments and successful missions of our troops. Security staff were responsible for all other tasks; in addition, they also transported the injured fighters, delivered and prepared food. The quartermaster delivered food to an agreed location, from which our staff collected it in the evening. I don't remember the exact number of patients treated at this hospital, but there were many."

\section{Partisan DOctor Robert Kukovec AND his notes}

The last doctor in the "Celje" hospital was the previously mentioned Dr Robert Kukovec. Two days before the Second World War broke out, he arrived at the surgical clinic in Ljubljana to work as Dr Božidar Lavričs assistant (Zupanič Slavec, 2016-2021; Cf. also: Soban \& Rupreht, 2006, p. 185). In May 194I, he passed his state assistant's exam with distinction and worked as Assistant Professor at the clinic before joining the Partisans in July 1943. As one of the first surgeons in the region of Dolenjska, he was sent to Croatia, where he began to establish partisan medical stations. In the summer of 1944, he returned to the liberated area in Bela Krajina and was sent to Styria as the main surgeon of the $4^{\text {th }}$ Operative Zone (Kukovec J., n.d.). In Ljubno, Kukovec's work involved a variety of activities. He cared for both the injured fighters and the locals. He also organized medical courses for medics and medical clerks, scrub nurses and anaesthesiologists. He was a prominent personality, as is evident from the notes of a fellow doctor, Dr Ivan Cestnik:

"It gave me great pleasure to listen to Dr Kukovec speak with great fervency about his medical and surgical experience from France and elsewhere around the world. His words were corroborated with gestures. Driven by youthful enthusiasm, he was a master of partisan improvisation, improving and passing on knowledge to everyone involved in caring for our patients. [...] He was an exceptional organizer and an equally distinguished instructor. In the shortest of periods, he was able to provide practical training to medics, hygienists and scrub nurses, who were deployed to medical facilities and units. The training course was the responsibility of the Division Medical Training Unit of the $4^{\text {th }}$ Operative Zone, which sent the most promising medics to attend Dr Kukovec's course. As young medical doctors, we trained future brigade medics under his supervision. We taught them how to administer first aid to the wounded, resuscitate, apply the Esmarch bandage, carry the injured on a stretcher, improvise a splint, dress wounds on all parts of the body, disinfect, sterilize, etc." (Cestnik, 1951, pp. 103-104) 
After the German offensive on the liberated territory in December 1944, Kukovec was reassigned to the "Celje" hospital in January 1945, serving as its (last) superintendent until 15 April 1945 (ARTOUR, n.d.). Working as a doctor in Ljubno, he described the situation in the Upper Savinja Valley as follows:

"I944 is near its end. Before the winter, we were all convinced we'd be free by now. No one ever thought we would have to spend another winter in the woods. Recently, we've had to work a lot. Excessively so. The injured are being admitted around the clock. We are under ever greater pressure from the enemy and from the weather. It's late November, early December. The hilltops are already covered in snow, there's mud in the valley. And then there's rain again, followed by combat. The injured frequently arrived naked, half-frozen, and starving. We gave them what we could: medical care, food, a bed, some rest. The local population helped us. There were always good people around who brought us liquor, apple cider, milk, etc." (Kukovec R., 1944-I945)

Doctor Robert Kukovec was one of the few individuals who recorded the events they witnessed during the war. He started a diary when he was sent to the "Celje" hospital as a surgeon. After Kukovec's death, his diaries were kept by his orderly Franci Juvan (Terčak, 1956, p. 456). The original documents have been lost; however, the Museum of Recent History in Celje keeps a transcript of the diaries in its archives. ${ }^{3}$ Although the literature refers to the document as a diary, this cannot be confirmed, given that the entries are not dated, and some chapters have headings (e.g., The First Offensive, Betrayed, The Second Offensive, Our Home). The notes suggest that Kukovec took them irregularly, writing in retrospect when time permitted him to do so. Excerpts from his notes have already been published - Stane Terčak, the then curator in the Celje museum, published some of them in Planinski vestnik in 1956; they have also been included in the memoirs of other Partisan doctors (e.g. Ivan Cestnik, Virgil Krasnik).

Kukovec's notes open with a description of the departure from Ljubno:

"We are confronted with winter, an offensive, and a cruel fate. Never before was it so difficult to be a partisan than in the winter of 1944-45 in Styria. There were three of us. My orderly Franci, Lili, my scrub nurse, and I. Of course, I must not forget my little Bosnian horse that we used to transport medical supplies. [...] From Rastke, we followed the steep path across the moun-

3 I would like to thank Dr Marija Počivavšek, a historian from the Museum of Recent History Celje, for her guidance during the preparation of this article. 
tain. I wasn't really familiar with the terrain, but I was determined to find our station in order to avoid foul weather. A local showed me the way, and I made it to the station." (Kukovec R., I944-I945, pp. I-2; Novak, I984, pp. $685,686,692)$

Here is what he had to say about everyday life in the hospital:

"Our station was built in a pine forest so thick you would fail to see it even if standing right in front of it. Under a thick snow cover, it was even more inconspicuous. The station comprised six buildings: two barracks for patients with a capacity of 35-40 beds, small operating barracks, and little barracks for the staff, with beds, much like in a sleeping car. In December, an open fire was not allowed because of the smoke. We only lit a fire in the kitchen; yet, it was still cold and damp. (Kukovec R., I944-I945, p. 2)

We got up at different times. In case of danger, we got up at dawn, cleared away our belongings and prepared for retreat. If in no imminent danger, we also got up at dawn and made ourselves breakfast in the dark. What were we to do all day long? (Kukovec R., I944-1945, p. 13; Cf. also: Rogers, 2018, p.38, I48, 248)

We got up late and ate pap. It was extremely difficult to work in the hospital barracks because of the low temperatures. During the day, the patients were covered with blankets. After our work was done, we had nowhere to go. The administrative building was just as cold as the woods, and the kitchen wasn't much better. We walked around in coats, our feet freezing to the bone. From time to time, I took a walk. But the only way out of the station was up a steep footpath. Because of a poor diet, such an effort would have been both too taxing and useless. Even though the days were short, they felt like an eternity. We could barely wait for dusk to arrive so we could light a fire. After that, we were all relieved. We had some carbide left, so that we could read at night for a while. After we lit a fire in the barracks, standing next to the stove and in the upper bunks felt quite cosy, while the lower beds were always cold. Since we didn't light a fire at night, we used four blankets to keep ourselves warm. The worst thing was getting up in the morning. Of course, we were unable to perform surgery during the day, but only at night when the operating barrack was heated. (Kukovec R., I944-1945, p. 3)

Occasionally, we were overwhelmed by the cold, hunger, fear, and idleness. I don't know which of these was worse. Cold and hunger destroy you physically, while fear and idleness, mentally. (Kukovec R., I944-I945, p. I4) 
We were reduced to a vegetative state - all that was left was survival and daily sustenance. And idleness. I would have subscribed to such a primitive lifestyle, even for the future, if only I could work again: work in a hospital and operate. (Kukovec R., 1944-I945, p. 15)

As soon as there was a little bit of sunshine, the Englishman Stephen ${ }^{4}$ and I went "sunbathing". We dug a hole in the snow, covered it with pine branches and blankets and wrapped ourselves in blankets. It felt like Switzerland. But we were freezing cold. Being around the Englishman all the time, I managed to brush up my English." (Kukovec R., 1944-1945, p. 3)

About food:

"We made it through Christmas and the New Year. The holidays were pretty much like all other days. We got some apple cider and pork from the valley, and that was it. Except for that, the diet had become extremely dull. Potatoes, beans with slices of dried fruit, cooked meat, pap, and dumplings. Fat was in particularly short supply. We also lacked salt.

Our meals were meagre, usually comprising cold food. We always kept the bread for the offensives. Our main meal was dinner, which we started preparing immediately after sundown. We were starving by the time it got dark. Franci used to cook until the big offensive. Once I tested my culinary art in an attempt to stew dried fruit. By accident, a bar of soap ended up in the cooked compote, disintegrating in the process. Well, we ate that too, but Franci never allowed me to cook again. After the big offensive, Lili came to us and cooked for us, Franci serving solely as a quartermaster thereafter. We got food from different people. The quartermaster detachment occasionally provided us with meat. We also had roasted roe deer twice. The farmers from the area brought us the provisions, especially milk, vinegar and potatoes. Lili once gave us the royal treat of noodle soup.

In April, we picked dandelion leaves to make a salad." (Kukovec R., I944I945, P. 2, I4, I5)

About the devoted hospital staff:

"Yeah, our boys really work hard. They are the silent, anonymous heroes of labour and self-sacrifice. Most of them are former patients who came to the

4 Stephen Heath Parker was a survivor of an RAF bomber that crashed near Ljubno on 17 October 1944. Three crew members successfully bailed out, including Parker, who was seriously injured and taken to the "Celje" hospital; four airmen from the plane died in the crash. Parker was taken prisoner on 13 March 1945, when the Germans discovered the hospital. He survived the war as a POW (Žgajnar, 2012, p. 327-336). 
station as wounded partisans and stayed as staff members when needed; they were almost buried alive. The location of our station had to remain a secret, so they were never allowed to leave the station unless on duty. They can only leave at night when they go to collect other wounded fighters, food, or other equipment. They navigate through steep, rocky pathways and carry heavy loads into the station at night. During the day, they have to keep guard, prepare the firewood, bring water and maintain order. There are no events to attend here, no singing, no fun. Our station is the quintessence of confidentiality." (Kukovec R., 1944-1945, p. II)

About the importance of writing:

"I passed the time in my own way. I simply took up writing. One way or another, time goes by; if nothing else, I will be able to look at these lines someday and remember the past. (Kukovec R., 1944-1945, p. 15)

I spent many hours in this recon spot. Sometimes, I sunbathed to warm up my body like a lizard; another time, I watched the planes for hours on end, and other times still, I read or wrote, first about professional matters, and then about our life. Will anybody ever be interested in these lines? Will they be able to grasp everything we've been through, waiting and hoping? Why am I hiding this diary? If it fell into the hands of the Germans, they would learn too much. That is why I keep it in a safe spot and only bring it out when I write. Maybe one day, it will be left behind under a rock during an offensive, and unless I return, nobody will ever find it." (Kukovec R., 1944-1945, p. 13)

Fate dealt Dr Robert Kukovec a cruel hand because he died just a few days before the end of the war. The circumstances of Kukovec's death are not entirely clear. According to the testimony of Lizika Podlesnik, the sister of Kukovec's orderly Franci Juvan, the Germans caught him by accident on a nearby farm in mid-April 1945 and murdered him a few days later (ARTOUR, n.d.).

"Dr Kukovec was captured sometime mid-April. The German police took him to Ljubno. The Commander of Ljubno offered him freedom in exchange for treating his soldiers. Dr Kukovec refused. A few days short of the final collapse of the Third Reich, the Germans were shooting non-stop. The same night, Dr Kukovec was taken away. It will probably remain a mystery how he was murdered. A few days later, the locals found his body and buried it. His orderly, Franci, gave Dr Kukovec's diary to Kukovec's parents." (Podlesnik Juvan, 1955)

About the longing: 
"I saw the first butterfly today and the first leaf shooting from a stem. I watched winter and spring from here. I knew every single dry patch on the opposite hillside, comparing them every day in the morning and in the evening to see if they had grown any bigger. I saw trees turning green on this hill, I saw the meadows as they turned green. Oh spring, how we yearned for you the whole winter! We were certain that whoever lived to see you, would also live to see a new life. [...] Lying on the ground, I watched the blue skies, with my thoughts racing back and forth, avoiding the present. Keep looking ahead, ahead towards freedom. But it's not here yet. It will come, but who will be there to see it? From this spot, you get a good view of Ljubno and the church at Rosulje through the trees. I don't know if anybody has ever admired a work of art with as much yearning as I admired this little church. For me, it was a symbol of life, a symbol of freedom. (Kukovec R., 1944-1945, p. 13)

Long days, I don't know how I ever managed to get through you. All I remember is that my bones ached from lying down. I must have been looking ahead, dreaming about the days to come. About the spring, about warm weather, about the beautiful, long roads we'd walk again, about a good book, about work, about Beethoven's or Tchaikovsky's symphonies. [...] And we pulled through; we had to. We had no choice: a bullet and surrender, on the one hand, or hope and dreams, on the other. No, no, let us not give up. We still have a life ahead of us, beautiful new life. Our struggle was not in vain. We have another, far brighter future ahead of us. A new country, new people, new ideals. Dreams, hurry up, leap up to the firmament and draw dawn more beautiful than any we have ever seen. Seeing this moment is worth the wait and endurance. (Kukovec R., 1944-1945, p. 14)

As it turned out, Dr Robert Kukovec's yearning for freedom, as reflected in his notes, remained unfulfilled.

Translated by Simon Zupan 


\section{SOURCES}

\section{Archival sources}

1. Defar, B.-S. (14/11/1972). Memories of the Partisan healthcare system in the region of Kozjansko (typescript). F-35, m XI. Slovenia: Museum of Recent History Celje.

2. Krasnik, V. (17/10/1955 and 20/10/1958). Statement (typescript). F-35, m IV. Museum of Recent History Celje, Slovenia.

3. Kukovec, J. (n.d.). Biography of Dr Robert Kukovec (typescript). F-35, m IV. Slovenia: Museum of Recent History Celje.

4. Kukovec, R. (1944-1945). Journal (typescript - transcript). F-35, m IV. Slovenia: Museum of Recent History Celje.

5. Podlesnik Juvan, L. (28/11/1955). Statement (typescript). F-35, m IV. Slovenia: Museum of Recent History Celje.

6. Šeber, D. (6/3/1968). Statement (typescript). F-35, m IV. Slovenia: Museum of Recent History Celje.

7. Zupanc, I. (n.d.). Statement (typescript). F-35, m IV. Slovenia: Museum of Recent History Celje.

\section{Online sources}

1. Wikipedija (2021). Julije Budisavljević. https://hr.wikipedia.org/wiki/Julije_Budisavljević

2. Wikipedia (2019). Maurice Chevassu. https://en.wikipedia.org/wiki/Maurice_Chevassu

3. Združenje borcev za vrednote NOB Zgornje Savinjske doline (2021). Organizacija partizanske sanitete v Zgornji Savinjski dolini. http://zb-nob-zgornja-savinjska.si/dediscina-nob/partizanske-bolnice/organizacija-partizanske-sanitete-v-zgornji-savinjski-dolini/

4. Nature (1938). Prof. René Leriche. Nature, 141, 963-964. https://www.nature.com/ articles $/ 141963 \mathrm{cO}$

5. ARTOUR - Learn by Moving (n.d.). Robert Kukovec (1910-1945). https://ar-tour. com/guides/zdravniske-legende-maribora/robert-kukovec-19101945.aspx

6. Wikipedija (2018). Sergej Nikolajevič Saltykov (patolog). https://hr.wikipedia.org/wiki/ Sergej_Nikolajevič_Saltykov_(patolog)

7. SIstory - Zgodovina Slovenije (2011-2021). Statistički godišnjak Kraljevine Jugoslavije / Annuaire statistique Royaume de Yougoslavie. (1940). https://www.sistory.si/11686/1065

8. Zupanič Slavec, Zvonka (2016-2021). Božidar Lavrič. SAZU, https://www.sazu.si/clani/bozidar-lavric 


\section{LITERATURE}

1. Cestnik, I. (1951). Iz spominov partizanskega zdravnika na Štajerskem. Priroda, človek in zdravje, 6(4/5).

2. Fajdiga, M. (1998). V objemu človečnosti: Partizansko zdravstvo na Slovenskem 19411945. Ljubljana: Zveza društev vojnih invalidov Slovenije.

3. Fettich, J. (1993). Medicinska fakulteta. In Enciklopedija Slovenije, 7 (pp. 35-36). Ljubljana: Mladinska knjiga.

4. Horvat, M. (2011). Klara Kukovec (1883-1979), prva zdravnica v Trstu in Mariboru. In Historični seminar 9 (pp. 31-53). Ljubljana: Založba ZRC, ZRC SAZU.

5. Krajevni leksikon Dravske banovine (1937). Ljubljana: Zveza za tujski promet za Slovenijo v Ljubljani, 16-18.

6. Krasnik, V. (1959). SVPB »C«. 7 dni, IX(34), 1-2.

7. Kregar, T. (2009). Vigred se povrne: Druga svetouna vojna na Celjskem. Celje: Muzej novejše zgodovine.

8. Kukovec, R. (1945). O zdravljenju kostolomov v naših prilikah. Partizanski zdravstveni vestnik - Glasilo sanitetnega oddelka Glavnega štaba Slovenije. April 1945 (9, 10), 34-44.

9. Mrvič, S. (1974). Partizanska saniteta na Kozjanskem. In Celjski zbornik 1973-1974 (pp. 183-213). Celje: Kulturna skupnost.

10. Novak, J. (Ed.). (1984). Zbornik dokumentov in podatkov sanitetne službe v narodnoosvobodilni vojni na Slovenskem 1941-1945. Knjiga 3 (1. november 1944 - 28. februar 1945). Ljubljana: Sekcija za partizansko saniteto Slovenskega zdravniškega društva, Zveza zdravniških društev.

11. Planinšek, F. (1977). Razvoj javnega zdravstva v Celju. In Celjski zbornik 1975-1976 (pp. 511-518). Celje: Kulturna skupnost.

12. Počivavšek, M. (2018). Zdravstvo na Celjskem med drugo svetovno vojno. Arhivi, $41(1), 157-170$.

13. Rogers, L. (2018). Partizanski kirurg. Ljubljana: Cankarjeva založba.

14. Soban, D. \& Rupreht, J. (2006). Unesco - za varstvo zgodovine vojne medicine v Sloveniji. Zdrauniški vestnik, 75(3), 183-191.

15. Terčak, S. (1956). Partizanska bolnišnica Celje. Planinski vestnik, 56(8), 401-408, (9), 455-464.

16. Valenti, D. (1994). Partizansko zdravstvo. Enciklopedija Slovenije, 8 (pp. 262-263). Ljubljana: Mladinska knjiga.

17. Zaveršnik, H. (1996). Iz mojega sveta: Spomini. Celje: samozaložba.

18. Zupanič Slavec, Z. (2005). Razvoj javnega zdravstva na Slovenskem med prvo in drugo svetorno vojno in njegov utemeljitelj $d r$. Ivo Pirc. Ljubljana: Inštitut za varovanje zdravja RS.

19. Žgajnar, M. (2012). Zlomljena krila: Reševanje zavezniških letalcev na Slovenskem med drugo svetovno vojno. Ljubljana: ZZB NOB Slovenije, Svobodna misel. 


\section{SAŽETAK}

Drugi svjetski rat značio je cezuru u mnogim pogledima, uključujući i zdravstveni. Priličan broj liječnika i medicinskog osoblja u Sloveniji pridružio se partizanskom pokretu i pomogao organizirati partizansko zdravstvo. U partizanskim jedinicama zdravstvena je djelatnost započela 1942., a godinu dana nakon toga počela se razvijati mreža partizanskih bolnica koje su radile u najtežim uvjetima i u najstrožoj tajnosti. U njima je tijekom rata liječeno gotovo I5 000 ranjenika $i$ pacijenata. Od medicinskog osoblja u slovenskom partizanskom zdravstvu sudjelovala su 244 liječnika $i$ stomatologa, 26o studenata medicine, 38 medicinskih sestara $i$ više od 3000 priučenih bolničara. U članku je predstavljena partizanska bolnica "Celje" koja je radila na području Zgornje Savinjske doline. Posebno se ističu svjedočanstva partizanskih liječnika i drugih svjedoka koji iz prve ruke govore o životnom ritmu u toj, ali i u nekim drugim partizanskim bolnicama, pri čemu je najviše izvora pronađeno u bilješkama koje je u zadnjoj godini rata pisao kirurg dr. Robert Kukovec. Bio je jedan od rijetkih pojedinaca koji su tijekom rata bilježili događaje kojima su svjedočili. Iz njegovih zapisa može se razabrati sva tragičnost rata, mnogobrojni mračni i rjeđi svjetliji trenutci i iznimna žudnja za slobodom koju on sam, nažalost, nije dočekao. Umro je nepunih mjesec dana prije kraja rata.

Ključne riječi: Drugi svjetski rat, Slovenija, Štajerska, povijest zdravstva, partizansko zdravstvo, partizanska bolnica, partizanski liječnici 